\section{Output of Electrical Energy by Frog-Skin}

If a piece of frog-skin, mounted with glucose Ringer solution on both sides, is connected in series through two calomel electrodes with a micro-ammeter, a current may be observed to flow through the eircuit for many hours. With a piece of skin $1.6 \mathrm{~cm}^{2}$ in area in a circuit of total resistance $1,500 \mathrm{ohms}$ the current is $20-30 \times 10^{-6}$ amperes during 12 hours after setting up.

Between $0^{\circ} \mathrm{C}$. and $30^{\circ} \mathrm{C}$. the resistance of the skin falls steadily, the potential rises to a maximum at about $20^{\circ} \mathrm{C}$. and then falls off, and the current rises to a maximum at about $25^{\circ} \mathrm{C}$. before decreasing. The output of electrical energy by the skin can be calculated as equivalent to the Joule heat developed in the circuit. This was found for four different skins to lie between 5 and $9 \times 10^{-3}$ calories per minute per gram dry weight of ventral skin at $20^{\circ} \mathrm{C}$. It has been shown ${ }^{1,2,3}$ that when the ionic composition of the solution is constant the frog-skin potential is maintained by oxidation processes. It is of interest, therefore, to see what fraction of the energy released by oxidation may appear as electrical energy. The respiratory quotient of the skin of Rana temporaria is $0.97^{4}$. The average oxygen consumption of frogskin $^{3}$ was found to be $20 \times 10^{-3}$ c.c. oxygen per minute per gram dry weight at $20^{\circ} \mathrm{C}$. (other values are summarised by Adolph ${ }^{5}$ ). Assuming that molecules of $\left(\mathrm{C}_{6} \mathrm{H}_{12} \mathrm{O}_{6}\right)_{2}$ are burnt and taking the heat of combustion per gram as 680,000 calories, it will be found that the energy released by oxidation processes is on the average $100 \times 10^{-3}$ calories per minute per gram dry weight at $20^{\circ} \mathrm{C}$. The electrical energy output calculated above is 5-10 per cent of this value.

The temperature coefficient of the electrical energy output for a rise of $10^{\circ} \mathrm{C}$. was determined for three skins and compared with the average $Q_{10}$ for respiration for four skins.

\begin{tabular}{|c|c|c|c|c|}
\hline & \multicolumn{3}{|c|}{$Q_{10} \begin{array}{l}\text { Electrical } \\
\text { Energy }\end{array}$} & $\begin{array}{l}Q_{10} \text { Energy from } \\
\text { Combustion. }\end{array}$ \\
\hline $\begin{array}{rr}0^{\circ} \mathrm{C}-10^{\circ} \mathrm{C} . \\
10^{\circ} \mathrm{C}-20^{\circ} \mathrm{C} . \\
20^{\circ} \mathrm{C}-30^{\circ} \mathrm{C} .\end{array}$ & $\begin{array}{l}2 \cdot 85 \\
1.4 \\
-\end{array}$ & $\begin{array}{l}1.99 \\
1.44 \\
-\end{array}$ & $\begin{array}{l}3 \cdot 90 \\
1 \cdot 41\end{array}$ & $\begin{array}{l}3 \cdot 6 \\
2 \cdot 0 \\
1 \cdot 9\end{array}$ \\
\hline
\end{tabular}

The power output is a maximum at $24^{\circ} \mathrm{C}$. for the electrical process and at $38^{\circ} \mathrm{C}$. for the respiratory processes of the skin. Lund and Moorman ${ }^{6}$ have found that values of $Q_{10}$ for potential and oxygen consumption of the skin of $R$. pipiens between $16 \cdot 4^{\circ} \mathrm{C}$. and $26 \cdot 4^{\circ} \mathrm{C}$. are $2 \cdot 14$ and $2 \cdot 01$ respectively. (In my work $Q_{10}$ for the potential in this interval is near unity.) They adduce this approximate equality in support of a theory of the skin potential based on "the flux equilibrium of the oxidation-reduction systems" in the cells of the skin. Since, however, the frog-skin does not behave as a reversible galvanic cell, the potential cannot be related directly to the energy released by oxygen consumption except on the lines indicated above.

There are also objections to the interpretation of the skin potential, which is measured between reversible calomel electrodes, in terms of oxidationreduction potentials which can only be measured with the aid of an inert metal electrode to act as an electron donor or acceptor ${ }^{3}$. The skin potential, like the injury potential of crab's nerve ${ }^{7}$, depends on oxygen consumption and also on the nature and concentration of the electrolytes present ${ }^{8}$. With these two factors in mind, further work is in progress in conjunction with Dr. R. J. Pumphrey, on the nature of the frog-skin potential.
Department of Zoology, Cambridge. April 14.

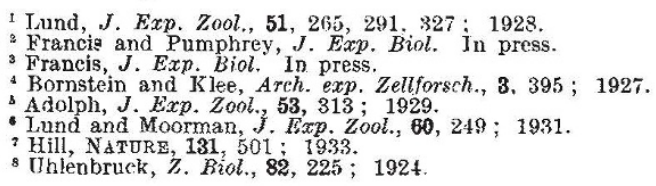

\section{The Astronomical Radiative Stability}

Astronomers are doubtless not unaware of the enormous radiative uniformity that is demanded by the permanence of organic life on the earth. If the temperature at the earth's surface were altered even for a single season from its actual value about, say, $27^{\circ} \mathrm{C}$. or $300^{\circ} \mathrm{K}$., by $50^{\circ}$ in excess or defect, all terrestrial organic life would be blotted out never to return. This would happen if even only once in the hundred million years demanded for terrestrial organic evolution the effective temperature of the solar radiating surface changed from the present mean value $6,000^{\circ} \mathrm{K}$. by $1,000^{\circ}$ in excess or defect, if it were a matter of steady state, while during the time of this change the stream of radiation incident on the earth would be altered in a proportion much greater. On current theories the difference between the top and bottom of the radiating solar atmosphere would be great in comparison with this figure, and lower down vast temperatures are soon reached. This shows how extremely steady the balance must be, and how slight the solar evolution must have been even in that vast time. As one result, the sunspot disturbances, even though they occupy only a very small part of the area of the solar disc, would have to be purely superficial phenomena. The output of radiation is very steady, as from a steady interior; yet the heavens are full of variable stars. Perhaps these considerations were remotely in view when long ago Whewell and Brewster were discussing the plurality of worlds, and Huxley championed the geologists against Kelvin.

Holywood, Co. Down.

Joseph LaRMor. May 14.

\section{The Combustion Problem of Internal Ballistics}

IN a recent paper on the combustion problem of intermal ballisties, we have attributed jointly to Love and Pidduck ${ }^{2}$ a statement as to the importance of including both temperature and pressure in the rate of burning law for colloidal propellants. Their paper was published in two parts, and the statement in question was made in Part 2, which was entirely the work of Dr. Pidduck. Our reference, in consequence, was misleading, and we desire to correct the error.

Research Department,

A. D. Crow.

W. E. Grimshaw.

Woolwich, S.E.18. May 23.

${ }^{1}$ Phil. Mag., 7, 15, 529; 1933.

2 Phil. Trans., A, 222, 599; 1922. 